\title{
Distribusi dalam Sistem Ekonomi Islam
}

\author{
Madnasir \\ IAIN Raden Intan Bandar Lampung \\ E-mail: madnasir_ekis@ymail.com)
}

\begin{abstract}
:
Distribution of economic activity in a government are very important. This is because the distribution itself became an objective of fiscal policy in a government with a form of taxation (taxes are both individual and corporate taxes). When talking about economic activity in the distribution, of course, will talk about the concept of "economy" that "offered" by the Islamic. Looking at how Islam introduced the concept of equitable distribution of wealth of the country through the distribution, which is certainly not independent of the state revenue the teachings of Islamic Shariah, such as waris, sadaqah, zakat and waqf.
\end{abstract}

Keywords: distribution, fiscal and government.

\section{Pendahuluan}

Di saat negara kita sedang dilanda krisis ekonomi yang berkepanjangan, salah satu pembahasan yang senantiasa menarik dalam menanggulangi krisis tersebut adalah seputar konsep distribusi ekonomi. Selama ini negara kita sering melihat hal ini dengan kaca mata sebelah, apalagi bercermin sejenak untuk melihat makna dan tujuan dari distribusi, khususnya distribusi dalam sistem ekonomi Islam. Padahal dengan lebih memperhatikan tujuan distribusi kekayaan negara, khususnya dalam ekonomi Islam, kiranya akan ada alternatif lain untuk dijadikan sebagai second opinion, sehingga akan menjadi suatu kebijakan di masa mendatang. Dengan demikian akan terselesaikan satu dari sekian banyak permasalahan yang menumpuk dan terkadang menurunkan tingkat optimisme kita sebagai warga negara, beralih menjadi sebuah sikap psimis yang tidak kunjung berakhir.

Berawal dari beberapa pemikiran yang mengemuka di dalam proses terciptanya distribusi yang banyak dibahas oleh para ekonom dan pemikir 
muslim, terwujudlah konsep dasar dari makna dan tujuan distribusi dalam ekonomi Islam. Tentu konsep tersebut tidak serta-merta dapat secara mudah dipraktekkan di suatu negara. Lalu pertanyaan selanjutnya, bagaimana negara dapat meningkatkan pendapatannya, melalui produksi, atau peningkatan aset negara yang dimiliki, dan lainnya? Pertanyaan semacam ini pantas untuk diangkat, karena adanya korelasi yang erat antara produksi dan distribusi dalam sistem ekonomi Islam.

Tulisan ini mencoba membandingkan konsep distribusi menurut pandangan beberapa pakar ekonomi Islam. Di antaranya adalah Anas Zarqa, Mahfooz Ahmad dan Abidin Ahmad Salama. Ketiganya lebih banyak menyorot dan mengkaji uraian-uraian yang berkenaan dengan distribusi.

\section{Definisi Distribusi}

Distribusi secara eksplisit telah dijelaskan Allah swt. dalam Alquran sebagai berikut:

"(Yaitu) mereka yang beriman kepada yang ghaib, yang mendirikan shalat dan menafkahkan sebagian rizki yang Kami anugerahkan kepada mereka.” (QS. Al-Baqarah: 3).

"Apa saja harta rampasan (fai') yang diberikan Allah kepada RasulNya yang berasal dari penduduk kota-kota maka adalah untuk Allah,untuk Rasul, kaum kerabatnya, anak-anak yatim, orang-orang miskin dan orang-orang yang dalam perjalanan, supaya harta itu jangan hanya beredar di antara orang-orang kaya saja di antara kamu. Apa yang diberikan Rasul kepadamu maka terimalah dia. Dan apa yang dilarangnya bagimu maka tinggalkanlah dan bertaqwalah kepada Allah. Sesungguhnya Allah sangat keras hukuman-Nya." (QS. AlHasyr: 7).

Selain itu dikemukakan pula bahwa segala apa yang ada di langit ataupun di bumi adalah milik Allah swt. Akan tetapi semuanya kembali pada bagaimana manusia mengelola sumber daya alam tersebut. Lebih jauh lagi bagaimana sebuah negara mampu mengelolanya, untuk selanjutnya mendistribusikan kembali pada masyarakat. Hal di atas sesuai dengan firman Allah dalam surat Hūd ayat 61, yang artinya: 
"Dia telah menciptakan kamu dari bumi (tanah) dan menjadikan kamu pemakmurnya.” (QS. Hūd: 61)

Kiranya jelas bahwa di samping adanya partisipasi dari masyarakat untuk mengelola sumber daya yang ada, negarapun memiliki peranan yang penting dalam mengalokasikan dan mendistribusikan pendapatan yang ada pada masyarakatnya (Karim, 1992: 85, 93).

Senada dengan pendapat di atas, Afzalur Rahman mengemukakan bahwa untuk mencapai keadilan ekonomi yang ideal dalam masyarakat, Islam menawarkan suatu gagasan yang sarat nilai dan menumbuhkan semangat di antara penganutnya. Gagasan tersebut adalah bahwa bantuan ekonomi kepada sesama, dengan niat mencari keridaan Allah semata, merupakan tabungan yang nyata dan kekal, yang akan dipetik hasilnya di akhirat kelak (Rahman, 1995: 96).

Adapun maksud distribusi ditinjau dari segi bahasa adalah proses penyimpanan dan penyaluran produk kepada pelanggan, di antaranya sering kali melalui perantara (Collins, 1994: 162).

Definisi yang dikemukakan Collins di atas memiliki kajian yang sempit apabila dikaitkan dengan topik kajian dalam tulisan ini. Hal ini disebabkan definisi tersebut cenderung mangarah pada perilaku ekonomi yang bersifat individual. Namun dari definisi di atas dapat ditarik perpaduan, di mana dalam distribusi terdapat sebuah proses pendapatan dan pengeluaran dari sumber daya yang dimiliki oleh negara (mencakup "prinsip take and give").

Adapun prinsip utama dalam konsep distribusi menurut pandangan Islam ialah peningkatan dan pembagian bagi hasil kekayaan agar sirkulasi kekayaan dapat ditingkatkan. Dengan demikian, kekayaan yang ada dapat melimpah secara merata dan tidak hanya beredar di antara golongan tertentu saja (Rahman, 1995: 93).

Ada juga pendapat yang menyatakan bahwa posisi distribusi dalam aktifitas ekonomi suatu pemerintahan amatlah penting. Hal ini dikarenakan distribusi itu sendiri manjadi tujuan dari kebijakan fiskal dalam suatu pemerintahan. Adapun distribusi, seringkali diaplikasikan dalam bentuk pungutan pajak, baik pajak yang bersifat individu maupun pajak perusahaan. Akan tetapi masyarakat juga dapat melaksanakan secara swadaya melalui pelem- 
bagaan Zakat, Infak dan Sedekah (ZIS). Dalam hal ini pemerintah tidak terlibat langsung dalam mobilisasi pengelolaan pendapatan ZIS yang diterima (Karim, 1992: 89-90).

Sementara Anas Zarqa mengemukakan bahwa definisi distribusi ialah transfer pendapatan kekayaan antarindividu dengan cara pertukaran (melalui pasar) atau dengan cara yang lain, seperti warisan, shadaqah, wakaf dan zakat (Zarqa, 1995: 181).

Demikian konsep ekonomi di bidang distribusi yang ditawarkan oleh Islam. Islam mengenalkan konsep pemerataan pembagian hasil kekayaan negara melalui distribusi tersebut, seperti zakat, wakaf, warisan dan lain sebagainya.

\section{Sumber Pendapatan Negara}

Ada beberapa kriteria yang mendukung optimalisasi distribusi dalam aktifitas ekonomi sebuah negara. Distribusi tidak dapat optimal tanpa ditopang oleh kriteria-kriteria tersebut, yang merupakan pondasi kuat bagi eksistensinya. Kriteria-kriteria itu adalah (Zarqa, 1995: 182-184):

1. Pertukaran; Kriteria ini mengacu pada konsep di mana orang berhak mengeluarkan pendapatannya untuk didistribusikan kepada orang lain, sehingga berimplikasi pada adanya fondasi yang solid dalam menunjang terbentuknya kemanusiaan yang adil.

2. Kebutuhan; Pendistribusian tersebut haruslah disesuaikan dengan tingkat kebutuhan masing-masing individu.

3. Kekuasaan atau negara; Peran kekuasaan atau negara turut mewarnai pendistribusian kekayaan negara secara lebih merata.

4. Norma-norma yang berkaitan dengan nilai sosial atau sistem yang sesuai dengan etika. Ketiga kriteria sebelumnya hendaknya lebih mengarah pada norma-norma sosial atau nilai etika yang berkembang dalam masyarakat. Contohnya adalah alokasi distribusi pendapatan nasional hendaknya lebih diarahkan pada beberapa ilmuan atau ulama'. Demikian pula alokasi modal hendaknya lebih mengarah pada otoritas publik guna mewujudkan peningkatan pendapatan masyarakat. 
Senada dengan beberapa uraian di atas, menyangkut prinsip keadilan dan pemerataan distribusi, Yusuf Qarḍāwī mengemukakan bahwa perbedaan pendapatan dan pemerataan kesempatan itu termasuk pula dalam prinsip keadilan. Selanjutnya Qarḍāwi mengemukakan beberapa faktor yang turut mempengaruhi proses pendistribusian perbedaan pendapatan. Faktor tersebut adakalanya merupakan karunia yang diberikan Allah tanpa adanya campur tangan manusia, adakalanya merupakan nilai usaha yang dilakukan seseorang (Qarḍ̄āìi, 1995: 398).

Sumber pendapatan negara, khususnya dalam ekonomi Islam, lebih banyak ditinjau dari aspek sejarah. Hal ini dapat dilihat dalam beberapa pokok pembahasan yang banyak berlaku di masa awal-awal berkembangnya Islam dan masa-masa pemerintahan khulafaurrasyidin (Salama, 1995: 115 ; Lihat pula dalam Zarqa, 1995: 191-204).

Sebelum membahas lebih jauh tentang pembahasan yang menyangkut tentang "keadilan", perlu penjelasan sekilas tentang pola distribusi yang pernah diterapkan oleh Umar ibn Khattab. Dalam hal distribusi yang berkenaan dengan harta bergerak, Umar melaksanakan hukum Allah yang berkaitan dengan permasalahan tersebut. Ia mengambil seperlimanya (khumus), dan membagikan empat perlima (4/5) lainnya kepada masingmasing tentara yang turut membela panji Islam (ikut perang). Akan tetapi berkenaan dengan tanah-tanah pertanian, Umar berpendapat bahwa tanahtanah itu harus disita dan tidak dibagi-bagikan. Tanah pertanian tersebut dibiarkan seolah-olah merupakan milik negara di tangan pemilik aslinya (warga setempat). Kemudian mereka ini dikenai pajak (kharāj). Hasil pajaknya dibagi-bagikan kepada seluruh masyarakat muslim setelah disisihkan untuk gaji tentara yang ditempatkan di pos-pos pertahanan -seperti Basrah dan Kufah di Iraq- dan negeri-negeri yang terbebaskan. Tentara pendudukan yang tinggal di sana tentu memerlukan ongkos. Karenanya jika tanah-tanah itu habis dibagikan, tentu akan muncul masalah seputar logistik buat para tentara itu. Sayang, kebanyakan sahabat menolak pendapat Umar tersebut (Madjid, 2000: 392-393).

Pendistribusian kekayaan negara haruslah dilaksanakan dengan beberapa pertimbangan yang matang dan penuh dengan perhitungan. Sehingga konsep keadilan yang dicita-citakan dapat benar-benar terwujud 
dan dirasakan oleh masyarakat. Hal tersebut sedikit dapat membentengi peredaran kekayaan di kalangan tertentu saja.

Menurut Mannan, beberapa aspek pembayaran dalam sistem ekonomi Islam, meliputi zakat, jizyah (pajak yang dikenakan pada non muslim sebagai imbalan untuk jaminan yang diberikan negara Islam pada mereka guna melindungi kehidupannya, harta bendanya dan lain sebagainya), kharāj (pajak bumi), barang rampasan perang, pajak pertambangan dan harta karun, bea cukai dan pungutan.

Secara tegas Mannan membandingkan bahwa terdapat perbedaan mendasar antara zakat dan jizyah, di mana zakat dipungut dari kaum muslim, sementara jizyah dan rikāz dipungut dari nonmuslim. Akan tetapi bukan berarti zakat merupakan pajak religius -meminjam istilah Mannan-, sementara jizyah dan kharaj merupakan pajak sekuler. Hal ini disebabkan negara Islam tidaklah dikategorikan sebagai negara sekuler. Selain itu ada pula hal menarik yang dikemukakan oleh Mannan, di mana terdapat perbeaaan tentang sifat pajak yang dikenakan pada pertambangan atau harta karun. Menurut mazhab Syafi'i dan Hambali, sebagaimana dikutip oleh Mannan, pajak ini dianggap sebagai zakat, sementara kaum Hanafi lebih condong mengkategorikan persoalan di atas sebagai harta rampasan perang (Mannan, 1993: 247-256).

Sedangkan menurut Zarqa, dalam hal pembahasan tentang sumber pendapatan negara, ia lebih cenderung memisahkan antara zakat dan zakat al-fiț sebagai sumber pendapatan negara. Hal ini berlandaskan pada perhitungan pembayaran zakat al-fitr yang pembayarannya cenderung sebatas satu hari saja -pada hari raya idul Fitri- dan hanya disalurkan pada golongan orang-orang yang miskin dan tidak mampu saja (Zarqa, 1995: 198).

Zarqa juga mengemukakan perbedaan pendapat mengenai kerjasama dalam hak kepemilikan antara muslim dan nonmuslim. Hal ini terlihat dari hadis Nabi yang dikutip Zarqa dari Bulüghu al-Marām karangan Ibnu Hajar, di mana Nabi bersabda:

"Muslim itu berserikat dalam tiga hal, yaitu air, rumput dan api" (HR. Abu Dawud dan Ibnu Majah, dari Ibnu Abbas)

Ada pula yang menambahkan garam sebagai salah satu bagian dari perserikatan muslim tersebut. Kiranya perlu menjadi perbandingan di sini 
dengan apa yang diriwayatkan dari Ahmad dan Abu dawud. Mereka cenderung memulai hadis tersebut dengan kalimat "manusia" dan bukan "muslim".

Selain itu dikemukakan pula perbedaan pendapat mengenai kebolehan mengelola barang tambang. Imam Malik mengemukakan bahwa barang tambang, meskipun milik pribadi tetap dianggap sebagai milik seluruh muslim, karena barang tambang tersebut tidak tampak di permukaan. Sementara Imam Syafi'i mengemukakan bahwa barang tambang tersebut adalah milik pribadi apabila dikelola oleh seseorang, baik itu muslim maupun non-muslim. Sementara Zarqa cenderung berpendapat sebagaimana pendapatnya Imam Syafi'i (Zarqa, 1995: 185-186).

Hal lain yang perlu diperhatikan adalah ketentuan yang menyangkut kepemilikan tanah jika ditinjau dari unsur waktu atau masa. Hal ini sebagaimana dikemukakan oleh Mannan, di mana kebolehan memiliki tanah yang telah dikelola dari tanah yang telah disia-siakan (mawāt), itu dalam jangka waktu tiga tahun. Berbeda dengan hukum Perancis yang membatasi kepemilikan tersebut selama 15 tahun, terlepas dari apakah tanah tersebut produktif atau tidak produktif (Mannan, 1993: 80). Lain lagi dengan alNabhani yang menyatakan tentang kebolehan pemilikan tanah mati bagi yang meghidupkannya, tanpa dibatasi waktu. Hal ini didasarkan pada hadis Nabi yang diriwayatkan oleh Jabir dari Rasulullah SAW yang bersabda:

"Siapa saja yang menghidupkan sebidang tanah mati maka tanah tersebut adalah hak miliknya" (HR. Tirmidhi)

Dengan kata lain disebutkan di sini, bahwa kebolehan pemilikan tanah mati tersebut berlaku pada muslim maupun nonmuslim, karena hadis itu sendiri bersifat mutlak (Al-Nabhani, 1999: 136).

Adapun yang terkait dengan air yang terdapat di dasar tanah, seperti mata air, si pemilik tanah tidaklah berhak untuk memiliki, karena semua orang bekerjasama dalam hal ini. Aturan dan pemikiran ekonomi dalam perubahan di atas, mengarahkan kita kepada kesimpulan, bahwa pemilik air (sumur) harus menyediakan air minum kepada masyarakat selain juga menyediakan air untuk dijual bagi irigasi ataupun dengan maksud dan tujuan komersial lainnya. 


\section{Keadilan dan Campur Tangan Negara dalam Distribusi}

Kaum sosialis mengecam masyarakat kapitalis, karena dalam masyarakat kapitalis, kekayaan dan kemewahan hanya dikuasai oleh sekelompok orang saja, sedangkan mayoritas masyarakatnya adalah miskin. Di samping itu terdapat praktek monopoli yang besar dan amat merugikan masyarakat dalam sistem kapitalis. Pada dasarnya, kritik kaum sosialis terhadap kapitalis tidak dapat disalahkan, akan tetapi mereka memerangi kebatilan dengan hal yang lebih batil. Kaum sosialis melakukan kegiatan monopoli yang lebih buruk dan lebih parah daripada monopoli kapitalisme. Negara sosialis menguasai semua sarana produksi seperti tanah, pabrik, ladang pertambangan dan sebagainya. Bahkan dalam sistem sosialisme terdapat jurang perbedaan dalam soal upah, di mana pada tahun 1962 upah tersebut mencapai perbandingan 1:50, yaitu gaji tertinggi sama dengan lima puluh kali lipat dari gaji kecil di Rusia (Qarḍāwì, 1995: 348-349).

Terlepas dari unsur normatif, Islam sebagai agama yang penuh rahmat dan barakah, memiliki konsep ekonomi yang sama sekali mengharamkan riba. Inilah yang tidak ada dalam sistem sosialisme maupun kapitalisme. Harta yang beredar di kalangan umat Islam benar-benar diharapkan menjadi harta yang bersih, dan lebih membawa pengguna harta tersebut pada nilai ibadah kepada Allah swt.

Berbicara masalah perbedaan ekonomi, Mahfooz Ahmad berpendapat bahwa keadilan distribusi dalam Islam tidak hanya terbatas pada konsep teori saja akan tetapi harus diimplikasikan perwujudannya terhadap seluruh lingkungan hidup. Selain itu, keadilan dalam distribusi haruslah bersifat fleksibel dalam kerangka kebijakan yang fundamental guna memecahkan masalah ketidak-merataan dan ketidak-adilan (Ahmad, 1995: 237).

Senada dengan uraian di atas, maka Qarḍāwi secara gamblang menggambarkan tentang bagaimana konsep keadilan yang sesuai dengan ajaran Islam. Menurut Qarḍāwì, maksud dari keadilan itu di antaranya adalah untuk meminimalisir keterpautan antara manusia dalam pendapatan yang berdasarkan unsur kesetiakawanan sosial (takāful) yang menyeluruh (Qarḍāwì, 1995: 411). Hal tersebut disebabkan adanya prinsip keadilan yang disodorkan Islam melalui kewajiban pada masyarakatnya untuk tidak 
membiarkan kaum yang lemah hingga mereka tidak merasa sebagai kaum yang terinjak-injak. Selanjutnya terdapat pula kewajiban bagi masyarakat muslim untuk membimbing kaum yang lemah, hingga mereka menjadi orangorang yang kuat dan mandiri.

Menurut Zarqa, ada beberapa aksioma dalam distribusi Islam, yaitu: (1) Seluruh masyarakat bekerjasama dalam mengelola sumber kekayaan alam yang dimiliki oleh negara; (2) Seluruh masyarakat bekerjasama dalam mengelola dan meningkatkan kekayaan publik; (3) Sumber-sumber yang tersedia bagi masyarakat muslim bukan merupakan usaha khusus dari setiap orang dan tidak diatur dari kepemilikan aset pribadi, akan tetapi ditentukan oleh undang-undang fai' serta dibebankan kepada perbendaharaan publik; (4) Masyarakat dianjurkan mengurangi sumber pendapatan pribadi dari sebuah kelompok dan pengurangan itu disalurkan melalui fai'. Adapun pengurangan tersebut, seperti: risiko buruh dan peningkatan biaya pendapatan; (5) Wakaf dianjurkan bagi mereka yang memiliki keuntungan yang besar, sehingga dapat memulihkan kondisi ekonomi masyarakat; (6) Perbedaan bentuk asuransi sosial haruslah didukung dan diakui untuk membantu individu yang mengalami kerugian karena adanya musibah yang menimpa; (7) Perbendaharaan publik menjamin masyarakat yang berpendapatan minimum, atau orang yang tidak dapat mencapai pendapatan setingkat pendapatan minimum; (8) Kebijakan ekonomi sangatlah dianjurkan guna mengurangi perbedaan (ketidak-merataan) dalam distribusi (Zarqa, 1995: 215-216).

Uraian di atas memberikan gambaran yang jelas pada kita bahwa pada dasarnya Islam sangatlah memperhatikan kemakmuran masyarakat secara umum. Islam lebih mementingkan distribusi yang merata bagi masyarakatnya.

Lebih lanjut Zarqa menyebutkan seputar distribusi pendapatan dalam negara Islam, sebagai berikut:

1. Hendaknya suatu negara atau pemerintahan lebih mengutamakan kesempatan kerja dan mewajibkan kerja bagi masyarakat yang sanggup melaksanakannya. Hal ini didasarkan pada anjuran atau dorongan Islam agar seseorang berusaha untuk bekerja, dan berkonsumsi dengan menggunakan hasil jerih payahnya sendiri serta tidak mengambil sedekah yang bukan haknya. 
2. Pemberlakuan undang-undang bagi suatu negara sangatlah diharapkan guna mengurangi kezaliman dan melarang persaingan yang tidak sehat dalam lembaga-lembaga Islam. Karenanya pemerintah harus mewujudkan persamaan hak dan kesempatan bagi masyarakatnya guna menghambat -jika tidak ingin dikatakan menghapus- berlanjutnya kemiskinan.

3. Suatu negara diperbolehkan memegang prinsip jaminan kebutuhan pokok berdasarkan tanggung-jawab hukum yang berlaku. Misalnya: prinsip zakat yang di dalamnya mencakup proses pendapatan dan pengeluaran yang relevan dengan kondisi modern.

4. Hendaknya suatu negara memiliki suatu strategi khusus guna meningkatkan pendapatan dan pendistribusian kekayaan negara di bidang ekonomi.

5. Negara diharapkan dapat mengeluarkan suatu peraturan yang dapat meningkatkan pertumbuhan ekonomi, melalui kekayaan masyarakat selain zakat.

6. Seharusnya peredaran kekayaan negara tidak hanya berkisar pada pemerintah semata, tetapi juga dapat dirasakan secara langsung oleh rakyat.

Uraian di atas juga memberikan penjelasan pada kita akan pentingnya peran pemerintah dalam meningkatkan kesejahteraan masyarakatnya. Adapun masyarakat hendaknya mendukung usaha pemerintah dalam meningkatkan kekayaan pendapatan negaranya, sehingga terciptalah apa yang diistilahkan dengan "masyarakat yang adil dan makmur".

Adapun objek-objek syariah dalam distribusi, sebagaimana dikemukakan oleh Ahmad, meliputi:

1. Memuaskan kebutuhan-kebutuhan seluruh makhluk terutama, dari pembayaran transfer. Ini dapat diaplikasikan pada seluruh umat manusia, bahkan mungkin juga terhadap hewan.

2. Menumbuhkan dampak positif dalam diri penderma, tujuan ini tidak pernah terpikir oleh para ekonom, kecuali jika ia memahami Alquran dan aturan-aturan syariah.

3. Menciptakan kebaikan atau perbuatan baik di kalangan masyarakat.

4. Mengurangi perbedaan dalam distribusi pendapatan dan kekayaan.

5. Memanfaatkan sumber daya alam yang dihasilkan oleh suatu negara, secara lebih baik. 
6. Menganjurkan seseorang -khususnya muslim- untuk bermurah hati, ia lebih tertarik untuk menjadi penderma (Ahmad, 1995: 211).

Mahfooz Ahmad, secara lebih rinci lagi menguraikan perbedaan jumlah penduduk di negara yang mayoritas penduduknya muslim. Negara Indonesia, Bangladesh, Pakistan dan Nigeria merupakan negara yang sangat tinggi jumlah penduduknya, hingga masing-masing mencapai lebih dari 60 juta orang. Adapun Turki, Mesir dan Iran jumlah penduduknya masingmasing antara 30-40 juta penduduk. Sedangkan Afghanistan, Iraq, Malaysia dan Sudan, masing-masing jumlah penduduknya antara 10-20 juta (Ahmad, 1995: 233-234).

Yang menjadi catatan di sini adalah tidak adanya hubungan antara jumlah penduduk dengan tingkat pertumbuhan ekonomi. Sebagai contoh Kuwait yang berpenduduk 1,03 juta orang adalah negara yang berpendapatan US\$ 11.726 perkapita. Sementara yang paling rendah adalah negara Bangladesh dengan US\$ 66 perkapita, sedangkan jumlah penduduknya adalah 76,8 juta orang. Adapun mengenai perbedaan pendapatan di negaranegara Islam, disebutkan bahwa dari 600 juta penduduk di negara-negara tersebut, hanya 46 juta atau sekitar 7,6 \% yang memiliki Gross Domestic Product (GDP) sebesar US\$ 1000 lebih perkapita. Hampir sekitar 2 sampai 3 dari penduduk mempunyai GDP kurang dari US\$250 perkapita. Selain itu, hasil pertumbuhan dari pendapatan negara yang tinggi, juga menjadi alasan yang tepat sebagai unsur penunjang pendapatan negara (Ahmad, 1995: 233-234).

Ahmad mengemukakan analisisnya mengenai distribusi dalam Islam yang merupakan alat untuk mengungkap ketidak-merataan pendapatan dari kekayaan negara yang ada. Tentunya semuanya merujuk pada ajaran Alquran dan Sunnah Nabi serta kerangka kebijakan yang muncul dan berkembang di masa pemerintahan khulafaurrasyidin (Ahmad, 1995: 237).

Selain itu tampak secara nyata bahwa pertumbuhan penduduk bukanlah merupakan satu-satunya cara untuk meningkatkan pendapatan kekayaan negara. Akan tetapi lebih pada bagaimana negara tersebut mengelola kekayaan yang ada. Untuk selanjutnya mendistribusikan kekayaan yang ada tersebut secara lebih adil. Karenanya tidak ada rakyat yang merasa diperlakukan tidak adil. Beberapa peristiwa yang terjadi di negara kita 
Indonesia memberikan penjelasan betapa distribusi yang "adil dan merata" sangatlah dibutuhkan.

Kajian mengenai distribusi ekonomi dari kebutuhan pokok, juga harus ditinjau dari sudut pandang sejarah. Pada abad ke-16 Masehi, kebanyakan dari negara Barat belum menyentuh "usaha" untuk meningkatkan kesejahteraan masyarakatnya. Demikian pula konsep buruh secara lebih teratur belum juga terwujud, apalagi tentang pengungkapan ide-ide dan pengaturan ekonomi dari sebuah pemerintahan atau negara. Pengaturan pemerintah yang ada, lebih banyak menyinggung hal-hal yang berkenaan dengan masalah perpajakan. Begitulah yang terjadi di negara Perancis. Orang-orang kaya yang bermukim di daerah Lyon cenderung memiliki inisiatif sendiri untuk merealisasikan penyisihan hartanya kepada masyarakat yang kurang mampu. Dan hal ini terus berlanjut sekitar tahun 1529 hingga tahun 1531. Sementara itu di negara Inggris pada tahun 1537, belum juga ditemukan gagasan riil untuk memperbaiki keadaan atau usaha yang tepat dari negara untuk kesejahteraan orang miskin dan tidak mampu (Salama, 1995: 128129).

Padahal pembahasan mengenai distribusi telah ada semenjak masa Nabi Muhammad saw., apa dan bagaimana sumber pendapatan negara serta pengeluaran negara yang ada pada masa tersebut. Hal ini dikemukakan sebagai perbandingan antara konsep distribusi dalam sistem ekonomi konvensional -kapitalis maupun sosialis- dengan konsep distribusi yang ditawarkan Islam.

Adapun Sumber Pendapatan Negara pada Masa Rasulullah saw. terdiri dari dua macam, yaitu pendapatan dari kaum muslim dan pendapatan dari kaum nonmusim. Pendapatan dari kaum muslim terdiri dari lima hal, yaitu: (1) Zakat; (2) Ușr; yaitu bea impor yang dikenakan pada pedagang sekali setahun, sebesar 5 \%; (3) Zakat fitrah; (4) Wakaf; Dan (5) Amwāl Fäḍilah, yaitu harta kaum muslimin yang meninggal tanpa adanya ahli waris, misalnya pajak yang imlannya cukup besar yang dibebankan pada orang kaya untuk menutupi pengeluaran negara, sebagaimana pada masa perang Tabuk. Selain itu ada pula shadaqah yang lain, seperti jatah seperlima (khumus) atau harta karun temuan sebelum periode Islam (rikāz). 
Sedangkan pendapatan dari Kaum Nonmuslim adalah: (1) Jizyah; yaitu pajak yang dikeluarkan untuk jaminan perlindungan jiwa; (2) Kharāj; yaitu pajak yang dipungut dari tanah yang dikelola orang nonmuslim setelah terjadinya peperangan; (3) Ușr (5\%); yaitu bea impor yang dikenakan pada pedagang sekali setahun.

Adapun jenis lain adalah Pendapatan Umum, yang secara umum dikelompokkan menjadi dua hal, yaitu: (1) Pendapatan primer dan sekunder; (2) Pendapatan lain, yaitu meliputi: (a) ghanīmah (rampasan perang); (b) Fai', yaitu harta rampasan yang diperoleh dari musuh tanpa melalui peperangan; (c) Uang tebusan untuk para tawanan perang; (d) Hadiah dari pemimpin atau negara lain.

Sedangkan Pengeluaran Negara selama Periode Kenabian, dapat dikelompokkan menjadi dua, yaitu pengeluaran primer dan pengeluaran sekunder. Adapun pengeluaran primer meliputi: (1) Biaya pertanahan, seperti persenjataan, unta, kuda dan persediaan; (2) Penyaluran zakat dan uṣr kepada yang berhak menerimanya menurut ketentuan Alquran; (3) Pembayaran gaji untuk gubernur (wāly), hakim ( qādi), guru, imam dan sebagainya; (4) Pembayaran sukarelawan; (5) Upah para pekerja; (6) Pembayaran utang negara, bantuan untuk musafir.

Sedangkan Pengeluaran Sekunder meliputi: (a) Bantuan untuk orang yang belajar agama di Madinah; (b) Hiburan untuk para delegasi keagamaan; (c) Hiburan untuk para utusan suku dan negara serta biaya perjalanan mereka, atau pengeluaran untuk duta-duta negara; (d) Hadiah untuk pemerintah lain; (e) Pembayaran untuk pembebasan kaum muslimin yang menjadi budak; (f) Pembayaran denda atas mereka yang terbunuh secara tidak sengaja oleh pasukan muslim; (g) Pembayaran utang orang yang meninggal dalam keadaan muslim; (h) Pembayaran tunjangan untuk orang miskin; (i) Tunjangan untuk sanak saudara Rasulullah saw.; (j) Pengeluaran rumah tangga Rasulullah; dan (k) Persediaan darurat, yang sebagiannya bersumber dari pendapatan pada Perang Khaibar (Karim, 2001: 65). 


\section{Penutup}

Dari beberapa uraian di atas mengenai sumber pendapatan dan proses distribusi negara, dapat disimpulkan bahwa pendapatan sumber kekayaan negara merupakan langkah awal yang harus diperhatikan oleh sebuah negara, guna mewujudkan distribusi yang adil dan merata bagi masyarakatnya. Selain itu, negara hendaknya memiliki "konsep" maupun kategori dalam menentukan nilai "keadilan" dari proses distribusi melalui pendapatan yang dimilikinya.

Partisipasi masyarakat untuk mengelola sumber daya yang ada, juga sangat penting. Sedangkan negara memiliki peranan yang penting dalam mengalokasikan dan mendistribusikan pendapatan yang ada pada masyarakatnya.

Sebagai seorang muslim, tentu kita meyakini bahwa model distribusi yang diuraikan di atas adalah model yang baik dan sangat memungkinkan aplikasinya di masa modern ini, terutama di negara kita yang sedang dilanda krisis ekonomi. Model tersebut hanyalah sebagian kecil dari uraian pendapat beberapa ekonom dan pemikir Islam di atas.

\section{Daftar Pustaka}

Depag RI, 1995. Alquran dan Terjcmahannya. Jakarta, Toha Putra.

Gulaid, Mahamoud and Mohamed Aden Abdullah (Ed.).). 1995. Reading in Publik Finance in Islam, Jeddah: Islamic Development Bank, Islamic Research and Training Institute.

Karim, Adiwarman A, 2001. Sejarah Pemikiran Ekonomi Islam,Yogyakarta, Pustaka Pelajar.

Karim, Rusli (Ed.,). 1992. Berbagai Aspek Ekonomi Islam, Yogyakarta, Tiara Wacana.

Madjid, Nurcholish. 2000. Islam: Doktrin dan Peradaban, Jakarta, Yayasan Wakaf Paramadina.

Mannan, Muhammad Abdul. 1993. Islamic Economic: Theory and Practice (Ekonomi Islam: Teori dan Praktek), terj. Nastangin, Yogyakarta, Dana Bhakti Wakaf. 
Nabhani, Taqiyuddin. 1999. Al-Niẓām al-Iqtiṣādi fỉ al-Islām (Membangun Sistem Ekonomi Altematif: Perspektif Islam), terj. Maghfur Wahid, Surabaya, Risalah Gusti.

Pass, Cristhopher, (dkk.). 1994. Dictionary of Economics (Kamus Lengkap Ekonomi), terj. Tumpal Rumapea dan Posman Haloho, Jakarta, Erlangga.

Qarḍ̄āì, Yusuf. 1997. Dauru al-Qiyam wa al-Akhlāq fi al-Iqtisāàd al-Islāmi (Peran Nilai dan Moral dalam Perekonomian Islam), terj. Didin Hafidhuddin dkk., Jakarta, Robbani Press.

Rahman, Afzalur. 1995. Economic Doctrines of Islam (Doktrin Ekonomi Islam II), terj. Soeroyo dan Nastangin, Yogyakarta, Dana Bhakti Wakaf. 